\title{
Бальна оцінка ефективності лікування хворих на травматичний кератит
}

\begin{abstract}
Резюме. Актуальність. Вивчення динаміки суб'єктивних клінічних симптомів при лікуванні пацієнтів із травматичним кератитом зі застосуванням додаткової оксигенації має практичне значення, оскільки під час запалення рогівки відбувається гіпоксія тканин. Мета роботи: вивчити динаміку інтегральних показників клінічних симптомів при лікуванні травматичного кератиту зі застосуванням гіпербаричного кисню. Матеріали та методи. До дослідження було включено 69 пацієнтів (69 очей) із травматичним кератитом віком від 18 до 75 років, серед яких 70 \% становили чоловіки. Всім пацієнтам до стандартної схеми лікування травматичного кератиту було включено гіпербаричну оксигенацію з емоксипіном один раз на добу протягом 6-10 днів тривалістю 40 хвилин за режимом 1,2 АТА в барокамері «Кка». Вивчалася динаміка клінічних суб'єктивних показників у пацієнтів основної та контрольної груп, виражена в балах за умовною шкалою, що розроблена нами. Результати та обговорення. Аналіз динаміки інтегральної бальної оцінки суб'єктивних проявів під час лікування хворих на травматичний кератит свідчить про суттєве поліпшення стану ока в пацієнтів основної групи (із застосуванням гіпербаричної оксигенації). Інтегральний показник суб'єктивних клінічних симптомів пацієнтів основної групи на кінець лікування зменшився на 90,94\% (p <0,001), що відповідає різниці між групами в 51,21\%. Порівняно з контрольною групою інтегральний показник включав зменшення середньої бальної вираженості відповідно: світлобоязні - 77,78\%, сльозотечі - 41,94\%, відчуття стороннього предмета - 41,67 \%, больового синдрому та печіння - по 36,84\% ( $<$ 0,001). Термін зникнення суб'єктивних клінічних симптомів основної групи

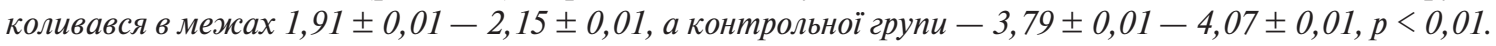
Висновки. Застосування додаткової оксигенації до традиційного лікування травматичного кератиту зменшує інтегральний суб'єктивний показник у балах пацієнтів основної групи на кінець лікування на 90,94\%, що відповідає різниці між групами майже в $49 \%$ ( $<$ 0,01). Використання ГБО-терапії сприяло одужанню хворих основної групи через 6,26 0,03 дня, а групи контролю - через 9,31 \pm 0,02 дня ( $p<0,01)$, тобто на 3,05 дня раніше.
\end{abstract}

Ключові слова: травматичний кератит; гіпербарична оксигенація; лікування

\section{Вступ}

На сьогодні травматичні кератити є однією з основних причин звернення хворих за офтальмологічною допомогою. Це обумовлено насамперед значним числом осіб, які на виробництві недостатньо дотримуються правил техніки безпеки, та зниженням настороженості населення стосовно профілактики травм органа зору [9-11]. Досить часто пацієнти з травмою ока звертаються за допомогою до офтальмолога на амбулаторний прийом із приводу травматичної ерозії рогівки. Більш тяжкі травматичні кератити (ТK) вимагають здебільшого стаціонарного лікування $[2,8]$.
Незважаючи на застосування сучасних методів лікування травматичних пошкоджень рогівки, нерідко у хворих спостерігається розвиток ускладнень, таких як бактеріальний кератит, ендофтальміт, помутніння рогівки та ін. [7, 12]. Тому лікування хворих на травматичні пошкодження рогівки вимагає подальшого вдосконалення.

Сьогодні доведена висока ефективність гіпербаричної оксигенації (ГБО) при лікуванні різноманітної очної патологіi $[1,3]$. Гіпербаричний кисень впливає на систему адаптації організму на всіх іiі рівнях: від системного до клітинного і молекулярного [4, 6]. По-

(c) «Архів офтальмології України» / «Архив офтальмологии Украины» / «Archive Of Ukrainian Ophthalmology» («Arhìv oftal'mologiï Ukraïni»), 2018

(с) Видавець Заславський 0.Ю. / Издатель Заславский А.Ю. / Publisher Zaslavsky 0.Yu., 2018

Для кореспонденції: Сакович В.М., Д3 «Дніпропетровська медична академія М0з України», вул. Вернадського, 9, м. Дніпро, 49044, Україна; е-mail: redact@i.ua

For correspondence: V. Sakovich, State Institution “Dnipropetrovsk Medical Academy of the Ministry of Health of Ukraine”, Vernadsky st., 9, Dnipro, 49044, Ukraine; e-mail: redact@i.ua 
зитивний ефект ГБО пов'язаний із загальними адаптогенними властивостями, що підвищують опір організму до різних стресів, сприяють посиленню дії низки медикаментозних препаратів (протизапальних, антиоксидантних), скороченню їх доз, термінів лікування пацієнтів. У зв'язку з цим доцільно подальше дослідження застосування ГБО як додаткового терапевтичного засобу при різній очній патології.

Мета роботи: вивчити динаміку інтегральних показників суб'єктивних клінічних симптомів при лікуванні ТК зі застосуванням гіпербаричного кисню.

\section{Матеріали та метоАи}

Для вирішення поставлених у роботі завдань обстежено та проліковано 69 пацієнтів (69 очей) із ТК віком від 18 до 75 років, з яких $70 \%$ становлять чоловіки.

Для вивчення ефективності лікування з урахуванням методу лікування пацієнти були розподілені на дві групи: основну групу становили 33 пацієнти (33 очей), що отримували загальноприйняте лікування із включенням ГБО; контрольну групу - 36 пацієнтів (36 ока), які отримували загальноприйняте лікування без включення ГБО.

Пацієнтам обох груп із першого дня захворювання було призначено загальноприйняте лікування, що включало: офлоксацин 0,3\% по 1 краплі 6-4 рази на добу, таурин 4\% по 2 краплі 4 рази на добу, декспантенол 5\% по 1 краплі гелю в кон'юнктивальний мішечок 4 рази на добу, метилетилпіридинол 1\% по 0,5 мл парабульбарно 1 раз на добу. При лікуванні пацієнтів основної групи до комплексної терапії додатково призначали ГБО щоденно упродовж 40 хвилин за режимом 1,2 АТА у барокамері «Ока» (6-10 днів).

При розподілі пацієнтів на основну і контрольну групи використано принцип рандомізації. Обидві гру- пи були ідентичні за перебігом захворювання, віком та статтю пацієнтів. Усі хворі проходили загальноприйняте офтальмологічне обстеження. Зміни стану переднього відрізку ока оцінювали до лікування та в його динаміці (на 6-ту, 15-ту добу від початку лікування).

Оцінка стану переднього відрізку ока проводилась за умовною шкалою $[5,11]$ і за нашою модифікацією. Здійснювався розрахунок сумарного інтегрального показника. Суб’єктивні клінічні ознаки (світлобоязнь, сльозотеча, почуття стороннього предмета, печіння, больовий синдром) оцінювались за такою шкалою: 0 - відсутня, 1 - незначна, 2 - помірно виражена, 3 - виражена.

На кожного хворого заповнювалася карта індивідуального обстеження пацієнта, яка відображала динаміку перебігу захворювання залежно від застосованої схеми лікування. Підсумкова ефективність лікування оцінювалась лікарем і пацієнтом за зменшенням або повним зникненням клінічних симптомів (погана -0 , задовільна -1 , добра -2 ).

Статистична обробка матеріалу проводилась методами варіаційної статистики, прийнятими в медицині та біології, з використанням критеріїв Стьюдента та Фішера за стандартними та спеціалізованими програмами.

\section{Результати та обговорення}

Результати наших досліджень свідчать про чітко виражений позитивний вплив запропонованого лікування на стан рогівки (табл. 1).

У динаміці лікування пацієнтів із травматичним кератитом відмічався ймовірний регрес основних клінічних ознак захворювання незалежно від схеми лікування.

Таблиця 1. Динаміка бальної оцінки під час лікування пацієнтів із травматичним кератитом

\begin{tabular}{|c|c|c|c|c|c|c|}
\hline \multirow{2}{*}{$\begin{array}{l}\text { Статистичні } \\
\text { показники }\end{array}$} & \multicolumn{3}{|c|}{ Основна група (абс., \%), n = 33} & \multicolumn{3}{|c|}{ Контрольна група (абс.,\%), n = 36} \\
\hline & Початок & Кінець & 15-та доба & Початок & Кінець & 15-та доба \\
\hline 1 & 2 & 3 & 4 & 5 & 6 & 7 \\
\hline \multicolumn{7}{|c|}{ Світлобоязнь } \\
\hline $\mathrm{M} \pm \mathrm{m}$ & $1,70 \pm 0,05$ & $0,18 \pm 0,01$ & $0,09 \pm 0$ & $1,72 \pm 0,05$ & $0,61 \pm 0,03$ & $0,14 \pm 0,01$ \\
\hline $\begin{array}{l}\Delta_{1} \\
\mathrm{P}_{1}\end{array}$ & - & $\begin{array}{l}-89,41 \% \\
(<0,001)\end{array}$ & $\begin{array}{l}-94,71 \% \\
(<0,001)\end{array}$ & - & $\begin{array}{l}-64,54 \% \\
(<0,001)\end{array}$ & $\begin{array}{l}-91,86 \% \\
(<0,001)\end{array}$ \\
\hline${\stackrel{\Delta}{\mathrm{P}_{2}}}_{2}$ & $\begin{array}{c}-1,16 \\
(>0,05) \\
\end{array}$ & $\begin{array}{c}-77,78 \\
(<0,001) \\
\end{array}$ & $\begin{array}{c}-35,71 \\
(<0,001) \\
\end{array}$ & - & - & - \\
\hline \multicolumn{7}{|c|}{ Сльозотеча } \\
\hline $\mathrm{M} \pm \mathrm{m}$ & $1,88 \pm 0,05$ & $0,18 \pm 0,01$ & $0,09 \pm 0$ & $1,89 \pm 0,05$ & $0,31 \pm 0,01$ & $0,17 \pm 0,01$ \\
\hline $\begin{array}{l}\Delta_{1} \\
\mathrm{P}_{1}\end{array}$ & - & $\begin{array}{l}-90,43 \% \\
(<0,001)\end{array}$ & $\begin{array}{l}-95,21 \% \\
(<0,001)\end{array}$ & - & $\begin{array}{l}-83,60 \% \\
(<0,001)\end{array}$ & $\begin{array}{l}-91,01 \% \\
(<0,001)\end{array}$ \\
\hline $\begin{array}{l}\Delta_{2} \\
\mathrm{P}_{2}\end{array}$ & $\begin{array}{l}-0,53 \% \\
(>0,05) \\
\end{array}$ & $\begin{array}{l}-41,94 \% \\
(<0,001)\end{array}$ & $\begin{array}{l}-47,06 \% \\
(<0,001)\end{array}$ & - & - & - \\
\hline \multicolumn{7}{|c|}{ Відчуття стороннього тіла } \\
\hline $\mathrm{M} \pm \mathrm{m}$ & $2,03 \pm 0,04$ & $0,21 \pm 0,01$ & $0,09 \pm 0,01$ & $2,00 \pm 0,04$ & $0,36 \pm 0,01$ & $0,14 \pm 0,01$ \\
\hline$\stackrel{\Delta_{1}}{\mathrm{P}_{1}}$ & - & $\begin{array}{c}-89,66 \% \\
(<0,001) \\
\end{array}$ & $\begin{array}{l}-95,57 \% \\
(<0,001)\end{array}$ & - & $\begin{array}{l}-82,00 \% \\
(<0,001)\end{array}$ & $\begin{array}{l}-93,00 \% \\
(<0,001)\end{array}$ \\
\hline $\begin{array}{l}\Delta_{2} \\
\mathrm{P}_{2} \\
\end{array}$ & $\begin{array}{l}1,50 \% \\
(>0,05) \\
\end{array}$ & $\begin{array}{l}-41,67 \% \\
(<0,001)\end{array}$ & $\begin{array}{l}-35,71 \% \\
(<0,001)\end{array}$ & - & - & - \\
\hline
\end{tabular}


Закінчення табл. 1

\begin{tabular}{|c|c|c|c|c|c|c|}
\hline 1 & 2 & 3 & 4 & 5 & 6 & 7 \\
\hline \multicolumn{7}{|c|}{ Печіння } \\
\hline $\mathrm{M} \pm \mathrm{m}$ & $1,91 \pm 0,05$ & $0,12 \pm 0,01$ & $0,03 \pm 0$ & $1,92 \pm 0,04$ & $0,19 \pm 0,02$ & $0,11 \pm 0,01$ \\
\hline$\stackrel{\Delta}{1}_{1}$ & - & $\begin{array}{l}-93,72 \% \\
(<0,001)\end{array}$ & $\begin{array}{l}-98,43 \% \\
(<0,001)\end{array}$ & - & $\begin{array}{l}-90,10 \% \\
(<0,001)\end{array}$ & $\begin{array}{l}-94,28 \% \\
(<0,001)\end{array}$ \\
\hline $\begin{array}{l}\Delta_{2} \\
\mathrm{P}_{2}\end{array}$ & $\begin{array}{l}-0,52 \% \\
(>0,05)\end{array}$ & $\begin{array}{l}-36,84 \% \\
(<0,001) \\
\end{array}$ & $\begin{array}{l}-72,73 \% \\
(<0,001) \\
\end{array}$ & - & - & - \\
\hline \multicolumn{7}{|c|}{ Больовий синдром } \\
\hline $\mathrm{M} \pm \mathrm{m}$ & $1,42 \pm 0,05$ & $0,12 \pm 0,01$ & $0,03 \pm 0$ & $1,47 \pm 0,05$ & $0,19 \pm 0,02$ & $0,08 \pm 0,01$ \\
\hline$\stackrel{\Delta}{P}_{1}$ & - & $-91,55 \%$ & $-97,89 \%$ & - & $-68,03 \%$ & $-94,56 \%$ \\
\hline $\begin{array}{l}\Delta_{2} \\
\mathrm{P}_{2}^{2}\end{array}$ & $\begin{array}{l}-3,40 \% \\
(>0,05)\end{array}$ & $\begin{array}{l}-36,84 \% \\
(<0,001)\end{array}$ & $\begin{array}{l}-62,50 \% \\
(<0,001)\end{array}$ & - & - & - \\
\hline $\begin{array}{c}\text { Інтегральний } \\
\text { показник }\end{array}$ & $8,94 \pm 0,24$ & $0,81 \pm 0,05$ & $0,33 \pm 0,01$ & $9,00 \pm 0,23$ & $1,66 \pm 0,1$ & $0,64 \pm 0,05$ \\
\hline${\stackrel{\Delta}{P_{1}}}_{1}$ & - & $\begin{array}{c}-90,94 \\
(<0,001)\end{array}$ & $\begin{array}{c}-96,31 \\
(<0,001)\end{array}$ & - & $\begin{array}{l}-81,56 \\
(<0,001)\end{array}$ & $\begin{array}{l}-92,89 \\
(<0,001)\end{array}$ \\
\hline${\stackrel{\Delta}{P_{2}}}_{2}$ & $\begin{array}{l}-0,67 \\
(>0,05)\end{array}$ & $\begin{array}{c}-51,21 \\
(<0,001)\end{array}$ & $\begin{array}{l}-48,44 \\
(<0,001)\end{array}$ & - & - & - \\
\hline
\end{tabular}

Примітки: $\Delta_{1} / \Delta_{2}-\%$ змін показника до лікування/до контрольної групи; $p_{1} / p_{2}$ - рівень значущості різниці середніх показника до лікування/до контрольної групи.

При порівнянні середніх величин ступеня вираженості світлобоязні в балах визначається ймовірне ( $\mathrm{p}<0,001)$ зменшення іiі в основній групі в кінці лікування порівняно з початком лікування на 89,41\%, а в контрольній групі - на 64,54 \%. При цьому на тлі практично однакових вихідних показників у групах (на початку лікування різниця становила $1,2 \%$; p > 0,05) вже в кінці лікування і через 15 діб терапії середній показник вираженості світлобоязні в основній групі був менший відповідно на 70,49 і 35,71 \%, ніж у контрольній групі ( $<$ 0,001). У кінці спостереження (через 15 діб) різниця між групами теж була вірогідною $(\mathrm{p}<0,05)$.

Середній термін зникнення світлобоязні в основній групі становив $1,96 \pm 0,01$ доби, а в контрольній $3,89 \pm 0,04$ доби $(\mathrm{p}<0,05)$, тобто з різницею 1,93 доби (рис. 1).

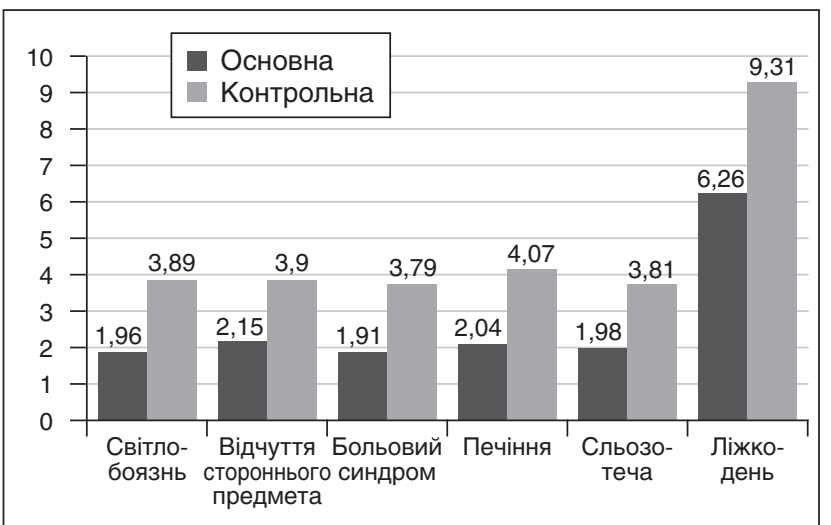

Рисунок 1. Порівняння термінів лікування основних суб'єктивних клінічних симптомів запального процесу та одужання хворих на травматичний кератит залежно від лікування $(M \pm m)$, дні $(p<0,01)$
Аналіз динаміки зменшення сльозотечі після лікування в обох групах пацієнтів свідчить, що в основній групі середній показник на кінець лікування зменшився з $1,88 \pm 0,05$ до $0,18 \pm 0,01$, тобто на 90,43\% ( $<<0,001)$. В контрольній групі динаміка зменшення сльозотечі теж була статистично значущою $(\mathrm{p}<0,001)$ і становила 83,60 \% на кінець лікування і 91,01\% на 15-ту добу.

При цьому на тлі практично однакових вихідних показників у групах (на початку лікування різниця становила $0,53 \%$, p > 0,05) на кінець терапії середній показник вираженості сльозотечі в основній групі був на $41,94 \%$ меншим, ніж у контрольній (p $<0,001)$, а через 15 діб - на 47,06\% (p <0,001).

Середній рівень відчуття стороннього предмета в оці в кінці лікування був вірогідно нижчим $(\mathrm{p}<0,001)$ у пацієнтів основної групи $(0,21 \pm 0,01$ бала) порівняно з контрольною групою $(0,36 \pm 0,01$ бала $)-89,66 \%$ проти контрольної групи, а зменшення цього показника на 15-ту добу лікування становило відповідно 95,57 та 93,00\% в основній та контрольній групах (p $<0,05$ між групами). Ймовірне зменшення ступеня вираженості відчуття стороннього предмета в пацієнтів основної групи після лікування порівняно з початком лікування спостерігалося в кінці та на 15-ту добу лікування відповідно на 41,67 і 35,71\%.

Середній термін зникнення відчуття стороннього тіла в основній групі становив $2,15 \pm 0,02$ доби, а в контрольній $-3,90 \pm 0,04$ доби $(\mathrm{p}<0,05)$, тобто різниця становила 1,75 доби (рис. 1).

Аналіз даних із динаміки показників печіння свідчить, що в обох групах спостерігається поступове його зменшення. В основній групі середній показник на кінець лікування зменшився з $1,91 \pm 0,05$ до 0,12 $\pm 0,01$ 
бала, тобто на 93,72 \% (p < 0,001). У контрольній групі динаміка зменшення печіння теж була статистично значущою ( $<$ 0,001) і становила 90,10\% на кінець лікування та 94,28 \% на 15-ту добу терапії.

При зіставленні середніх показників печіння в основній і контрольній групах у динаміці спостереження слід відмітити, що в кінці лікування и через 15 діб ці значення в групі зі застосуванням додаткової оксигенації були меншими відповідно на 36,84 і 72,73\% ( $<<0,001)$, ніж у контрольній групі.

Середній термін зникнення печіння в основній групі становив 2,04 $\pm 0,02$ доби, а в контрольній $4,07 \pm 0,05$ доби $(\mathrm{p}<0,05)$, тобто з різницею 2,03 доби (рис. 1).

Середні значення ступеня вираженості больового синдрому в балах до початку терапії в основній і контрольній групах пацієнтів були статистично порівнянні, а саме $1,42 \pm 0,05$ бала і $1,47 \pm 0,05$ бала відповідно ( $>>0,05)$. При цьому вираженість больового синдрому в пацієнтів на тлі застосування ГБО на кінець лікування знижувалася на 91,55\% (0,12 $\pm 0,01$ бала), а в контрольній групі - на 68,03\% (0,19 \pm 0,02 бала), що відповідає різниці між групами в $36,84 \%$ ( $<00,01)$. Через 15 днів після початку лікування різниця між середніми показниками больового синдрому в групах була суттєвою $(\mathrm{p}<0,001)$.

Середній термін зникнення больового синдрому в основній групі становив $1,91 \pm 0,01$ доби, а в контрольній $-3,79 \pm 0,04$ доби ( $<0,05)$ (рис. 1).

Середні значенння інтегрального суб'єктивного показника в балах до початку ГБО-терапії в основній і контрольній групах пацієнтів відповідно становили: $8,94 \pm 0,24$ бала та 9,00 $\pm 0,23$ бала ( $>>0,05)$. При цьому для пацієнтів основної групи на кінець лікування інтегральний показник зменшився на 90,94 \% - до $0,81 \pm 0,05$ бала $(\mathrm{p}<0,001)$, а в контрольній групі - на $81,56 \%$ - до 1,66 \pm 0,05 бала ( $<<0,001)$, що відповідає різниці між групами в $51,21 \%(\mathrm{p}<0,001)$. В контрольний термін після початку лікування різниця між показниками в групах не відмічалась ( $>>0,05)$.

Використання ГБО-терапії додатково до традиційної пацієнтів основної групи сприяло позитивній динаміці з боку органа зору. Одужання в цій групі хворих наставало через 6,26 $\pm 0,03$ дня, а в контрольній - через $9,31 \pm 0,02$ дня $(\mathrm{p}<0,01)$, тобто на 3,05 дня раніше (рис. 1).

Установлена наявність кореляційного зв'язку між одужанням пацієнтів основної групи та суб'єктивними симптомами. Аналіз зв'язків одужання пацієнтів із суб'єктивними симптомами свідчить про лінійний, прямий зв'язок середньої сили $(\mathrm{r}<0,6, \mathrm{p}<0,05)$ : зі сльозотечею $(\mathrm{r}=0,988, \mathrm{p}<0,05)$, печінням в оці $(\mathrm{r}=0,995$, $\mathrm{p}<0,05)$, больовим синдромом $(\mathrm{r}=0,897, \mathrm{p}<0,05)$, відчуттям стороннього предмета $(\mathrm{r}=0,950, \mathrm{p}<0,05)$, світлобоязню $(\mathrm{r}=0,936, \mathrm{p}<0,05)$.

Підсумкова ефективність лікування у $81 \%$ випадків була оцінена лікарем як добра, а в $19 \%$ - як задовільна. Пацієнти у 86,5 \% випадків охарактеризували ефективність лікування як добру, в 13,5 \% - як задовільну.
Таким чином, застосування гіпербаричної оксигенації в комплексному лікуванні травматичного кератиту значно покращує клінічні суб'єктивні показники і сприяє швидкому одужанню.

\section{Висновки}

1. Застосування гіпербаричної оксигенації в комплексному лікуванні травматичного кератиту характеризується більшою ефективністю, забезпечує стабільні клініко-функціональні результати в основній групі порівняно з контрольною: після лікування зменшення світлобоязні в основній групі порівняно з контрольною становило 77,78 \% (р < 0,001), сльозотечі - 41,94\% ( $<<0,001)$, відчуття стороннього предмета $-41,67 \%$ ( $<<0,001)$, больового синдрому та печінням в оці $36,84 \%$ ( $<<0,001)$, інтегрального показника $-51,21 \%$ $(\mathrm{p}<0,001)$.

2. Використання ГБО-терапії додатково до традиційної в пацієнтів основної групи сприяло позитивній динаміці з боку органа зору. Одужання в цій групі хворих наставало через 6,26 $\pm 0,03$ дня, а в контрольній - через $9,31 \pm 0,02$ дня ( $<<0,01)$, тобто на 3,05 дня раніше.

3. Підсумкова ефективність лікування у $81 \%$ випадків була оцінена лікарем як добра, а в $19 \%$ - як задовільна. Пацієнти в 86,5 \% випадків охарактеризували ефективність лікування як добру, в 13,5 \% - як задовільну.

Конфлікт інтересів. Автори заявляють про відсутність конфлікту інтересів при підготовці даної статті.

\section{Список Аітератури}

1. Беда Д.И. Комплексное лечение возрастной макулярной дегенерации с применением гипербарической оксигенации: Автореф. дис... канд. мед. наук: спеи. 14.01.07 «глазные болезни» / Д.И. Беда. - Красноярск, 2010. - 23 с.

2. Новый топический антибиотик «Окацин» в лечении гнойных язв роговицы / П.А. Бездетко, Н.В. Панченко, А.Ю. Савельева и др. // ІІ Міжнар. наук. конф. офтальмологів Причорномор'я: тези. - Одесса, 2004. - С. 16-17.

3. Гусова М.К. Токсическое поражение зрительного нерва при интоксикации алкоголем: Автореф. дис... канд. мед. наук: спец. 14.00.08. «глазные болезни», 14.00.45. «наркология» / М.К. Гусова. - М., 2008. - 15 c.

4. Елисеева Е.В. Гипербарическая оксигенация в офтальмологии: учебное пособие / Е.В. Елисеева. - Караганда, 2010. - 48 с.

5. Каменская Е.В. Влияние препаратов «Факовит» и «Тауфон» на активность окислительно-восстановительных ферментов в крови и слезной жидкости у больных поверхностным герпетическим кератитом / Е.В. Каменская, Г.И. Дрожжина // Офтальмол. журнал. - 2008. - № 1. - С. 27-32.

6. Кузьминов О.Д. Применение ГБО в офтальмологии / О.Д. Кузьминов, В.ЈІ. Лукич // Бюл. гипербарической биологии и медицины. - 2001. - № 1-4. - С. 76-85.

7. Майчук Ю.Ф. Оптимизация терапии болезней глазной поверхности / Ю.Ф. Майчук. - М., 2010. - 113 c.

8. Петруня А.М. Нарушение местного иммунитета у больных травматическим кератитом / А.М. Петруня, Фарук Исса Саид Ашур // Сучасні досягнення офтальмохірургї: наук.практ. конф. з міжнар. участю: тези. - К., 2010. - С. 176-177. 
9. Рыков С.А. Активность воспалительного процесса у больных герпетическим кератитом по уровню провоспалительных цитокинов в слезной жидкости / С.А. Рыков, М.А. Знаменская // Офтальмологический журннал. - 2009. - № 5. - С. 4-6.

10. Риков С.О. Особливості анамнезу та клінічного перебігу герпетичного кератокон'юнктивіту / С.О. Риков, М.А. Знаменська // Проблеми екологічної та медичної генетики і клінічної імунологї: зб. наук. праць. - Київ; Луганськ; Харків, 2007. Bun. 1-2(76-77). - C. 453-459.
11. Сакович В.Н. Применение флогэнзима в лечении герпетических кератитов / В.Н. Сакович, Т.С. Никитчина, Б.Д. Щербаков // Офтальмология. Восточная Европа. - 2012. - № 2. - C 141-145.

12. Пути оптимизации терапии поверхностных форм герпетического поражения роговицы / Л.А. Сухина, К.Э. Голубов, А.Ф. Смирнова, Г.В. Котлубей // Таврический медико-биологический вестник. - 2011. - T. 14, ч. 2(56). - С. 349-351.

Отримано 08.10.2018

Сакович В.Н.' , Острикова Т.A. ${ }^{2}$

1 ГУ «Анепропетровская медицинская академия» МЗ Украины, г. Анепр, Украина

${ }^{2}$ Анепропетровская клиническая больница железнолорожного транспорта, филиал Центра зАравоохранения

ПАО «Укрзализныця», г. Анепр, Украина

\section{Балмьная оценка эффективности лечения больных травматическим кератитом}

Резюме. Актуальность. Изучение динамики субъективных клинических симптомов при лечении пациентов с травматическим кератитом с применением дополнительной оксигенации имеет практическое значение, так как при воспалении роговицы происходит гипоксия тканей. Цель работы: изучить динамику интегральных показателей клинических симптомов при лечении травматического кератита с применением гипербарического кислорода. Материалы и методы. В исследование были включены 69 пациентов (69 глаз) с травматическим кератитом в возрасте от 18 до 75 лет, среди которых 70 \% составляли мужчины. Всем пациентам в стандартную схему лечения травматического кератита была включена гипербарическая оксигенация с эмоксипином один раз в сутки в течение 6-10 дней продолжительностью 40 минут по режиму 1,2 АТА в барокамере «Ока». Изучалась динамика клинических субъективных показателей у пациентов основной и контрольной групп, выраженная в баллах по условной шкале, разработанной нами. Результаты. Анализ динамики интегральной балльной оценки субъективных проявлений в процессе лечения больных с травматическим кератитом свидетельствует о существенном улучшении состояния глаза у пациентов основной группы (с применением гипербариче- ской оксигенации). Интегральный показатель субъективных клинических симптомов пациентов основной группы к концу лечения уменьшился на 90,94\% ( $<<0,001)$, что отвечает разнице между группами в 51,21 \%. По сравнению с контрольной группой интегральный показатель включал уменьшение средней балльной выраженности соответственно: светобоязни - 77,78 \%, слезотечения - 41,94 \%, ощущения инородного тела - 41,67 \%, болевого синдрома и чувство жжения глаза $-36,84 \%$ ( $<<0,001)$. Время исчезновения субъективных клинических симптомов основной группы колебалось в пределах 1,91 \pm 0,01 - 2,15 \pm 0,01 дня, а контрольной группы $-3,79 \pm 0,01-4,07 \pm 0,01$ дня, $\mathrm{p}<0,01$. Выводы. Применение дополнительной оксигенации к традиционному лечению травматического кератита уменьшает интегральный субъективный показатель в баллах у пациентов основной группы в конце лечения на 90,94 \%, что соответствует разнице между группами почти $49 \%$ ( $<<0,01)$. Использование ГБО-терапии способствовало выздоровлению больных основной группы через 6,26 \pm 0,03 дня, а группы контроля - через $9,31 \pm 0,02$ дня $(\mathrm{p}<0,01)$, т.е. на 3,05 дня раньше.

Ключевые слова: травматический кератит; гипербарическая оксигенация; лечение

\section{V.N. Sakovich1', T.A. Ostrikova² \\ 'State Institution "Dnipropetrovsk Medical Academy of the Ministry of Health of Ukraine", Dnipro, Ukraine ${ }^{2}$ Dnipropetrovsk Clinical Hospital of Railway Transport, Branch of the Health Protection Center of Public Joint Stock Company "Ukrzaliznytsia", Dnipro, Ukraine}

\section{Score evaluation of the treatment of patients with traumatic keratitis}

Abstract. Background. The study of the dynamics of subjective clinical symptoms in the treatment of patients with traumatic keratitis using additional oxygenation is of practical importance, since tissue hypoxia occurs in inflammation of the cornea. The purpose was to study the dynamics of integrated indicators of clinical symptoms in the treatment of traumatic keratitis with the use of hyperbaric oxygenation. Material and methods. The study included 69 patients (69 eyes) with traumatic keratitis aged 18 to 75 years, $70 \%$ of whom were men. In all patients, the standard treatment of traumatic keratitis included hyperbaric oxygenation with emoxipin once a day with a duration of 40 minutes, for $6-10$ days according to the 1.2 ATA regime in the Oka pressure chamber. The dynamics of clinical subjective indices was studied in patients of the main and control groups, expressed in points according to the conventional scale developed by us. Results. Analysis of the dynamics of the integral scores of subjective manifestations during the treatment of patients with traumatic keratitis indicates a significant improvement in the eye condition in main group (with the use of hyperbaric oxygenation). The integral index of subjective clinical symptoms in patients of the main group at the end of treatment decreased by $90.94 \%(\mathrm{p}<0.001)$, which corresponds to the difference between the groups of $51.21 \%$. Compared to the control group, the integral indicator included a decrease in the mean score: of photophobia - by $77.78 \%$, lachrymation - by $41.94 \%$, foreign body sensation - by $41.67 \%$, pain and smoking by $36.84 \%(p<0.001)$. Conclusions. The use of additional oxygenation along with traditional treatment of traumatic keratitis reduces the integral subjective score in the main group by $90.94 \%$ at the end of the treatment, which corresponds to the difference between the groups of almost $49 \%(\mathrm{p}<0.01)$. The use of hyperbaric oxygenation therapy promoted recovery of patients of the main group after $6.26 \pm 0.03$ days, and in control groups - after $9.31 \pm 0.02$ days $(\mathrm{p}<0.01)$, ie, 3.05 days earlier.

Key words: traumatic keratitis; hyperbaric oxygenation; treatment 